\title{
Thoughts on Strengthening the Personnel Files Management of Cadre in Colleges and Universities
}

\author{
Xinming Lu \\ Baoshan University, Yunnan, China, 678000
}

Keywords: colleges and universities; personnel files of cadres; management

Abstract: With the continuous deepening of the reform of the cadre personnel system in our country and the increasing frequency of talent flow, the traditional cadre personnel file management model faces new challenges. The paper analyzes the importance of cadres' personnel files and problems in the management of college cadres' archives, and puts forward countermeasures for the management of cadres' personnel files from aspects of hardware construction, staffing, sound system, standardized management, promotion of informatization, and improvement of utilization rate.

\section{Introduction}

The management of personnel files in colleges and universities is an important part of the personnel work of institutions of higher learning. The personnel files of cadres are organizations, personnel, and other relevant departments. According to the party's cadre policies, the personal history, political ideology, moral character, business abilities, work performance, and work achievements of cadres formed during the training, selection, and appointment of cadres have been formed. The original document material of the content. Under the conditions of the socialist market economy, cadres' personnel files that record and reflect the situation of talent in colleges and universities have an even more important role. Strengthening the management of cadres' personnel files and giving full play to the role of cadre archives is an important part of the organization of higher education institutions in the new era.

2. The main problems existing in the management of personnel files in colleges and universities

\subsection{The management approach is still dominated by traditional manual operations, and the entire process is cumbersome and complicated}

In accordance with the management requirements of the cadre personnel file work objectives, the materials collected for archiving shall be placed in the cadre archive within one month, and bound and archived once every two years. As a large number of new materials are added each year, file management personnel are constantly busy with the collection, bagging, sorting, dismantling, loading and ordering of materials, and a large number of simple, repetitive labors. As a result, file management personnel do not have time and energy to consider. Develop the internal information 
of the file. The old and outdated methods of file management and the cumbersome and complex procedures of the entire archives have not adapted to the requirements of the information age for the modernization of archives.

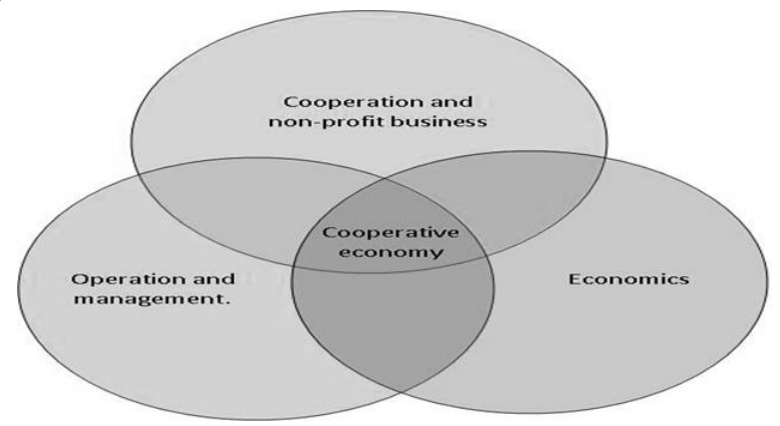

Fig.1 The Management of Cadre Personnel Files in Contemporary Colleges and Universities Taking the Economy Department as an Example

\subsection{The format of the archival material is not standardized and the content is incomplete}

With the introduction of competition mechanisms in social development and economic activities, more and more attention has been paid to the credentials of personnel files in terms of employment and promotion of positions. This requires that the source and content of each material in the personnel files must be true and reliable. Must be rigorously identified and carefully verified by the organization. However, in the actual personnel records management and related research, we found that in recent years, when some people fill in their resumes, the younger the age is, the smaller the age is, the earlier the service age is, the higher the academic qualification is. Some archival materials are either poor in paper or written in a ballpoint pen. The writing is vague or the format of writing top and top edges is not standardized, which is not conducive to the preservation and use of files.

\subsection{The lack of effective editing and research cannot provide efficient information services for the construction of talent teams}

At present, the cadre personnel files of local colleges and universities are generally managed by the archives office of the personnel department of the school organization, or placed in the school's general archives (room) by special personnel. Most of the management is based on paper files, and there are fewer management team personnel. Weak power, weary to cope with the collection, collation and binding of various archival materials. We do not have the time and energy to compile archival materials and computer input, and we cannot establish a fully-fledged talent pool. The adoption of personnel information can only rely on memory. If you are unfamiliar with the situation, you will not be able to get a clue. As a result, the information reflected by archival materials cannot be used to maximize efficiency, and information exchange between universities and research institutes is beyond discussion.

\section{Some Suggestions on Strengthening the Management of Cadre Personnel Files in Colleges and Universities}

\subsection{Strengthen education and enhance archival awareness}

Archival awareness refers to people's emphasis on archival and archival work. The emphasis should be placed on strengthening the awareness of archivists in the schools and colleges, especially 
the middle-level leaders and relevant management departments. Most of them are employed in recent years. There is still a lack of documentation and awareness of archives in their work. They often store materials in the hands of departments or individuals. Therefore, they should often be organized to contact the relevant laws and regulations formulated by the organizational department in actual learning, fully understand the status and role of archives in the management of universities, and conscientiously align the relationship between the management of cadres' personnel files and the organization of personnel management. Manage and use the archives of live cadres can really play the role of archives, making it an important support for the implementation of the "talent strategy" in colleges and universities.

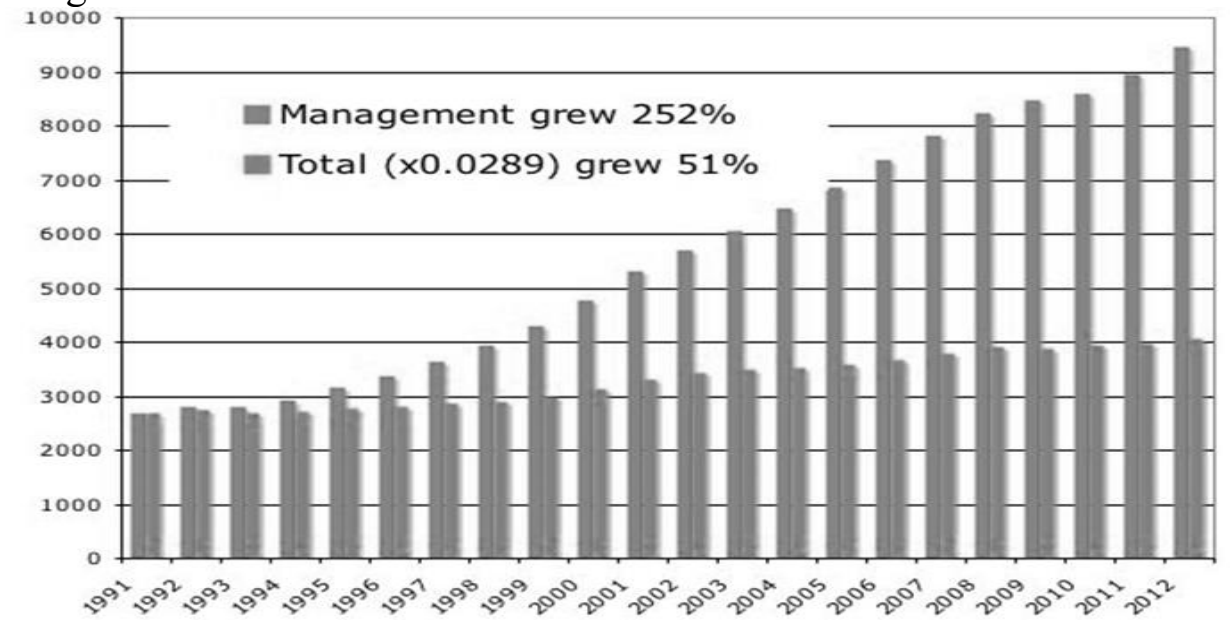

Fig. 2 The Cognition and Statistics of Personnel Records Management of University Archives Management in China

\subsection{Renew ideas and strengthen the innovation of management mode for college personnel files}

As a talent base for the society, colleges and universities are rich in human resources. Through cadres and personnel files, we must understand historically and comprehensively the cadres, "knowing people and doing good work," and "election and invigorating talents," and give full play to the role of college talents and improve their utilization. Make due contributions to economic development. We must focus on doing a good job in the basic work of personnel files for cadres and ensuring that personnel files are complete, truthful, accurate, and complete.

\subsection{The implementation of information management, improve the utilization of talent in colleges and universities}

The archives management department should assume the responsibility of mastering and providing information, change manual management methods, adopt modern methods, use computers, copiers, scanners, cameras, and personnel file management software, adopt scientific methods and Technology to collect, sort, identify, bind, keep, and use management personnel files. Actively conduct archival research and development, in accordance with the needs of building a talent team, establish a comprehensive and informative cadre personnel file information database system, provide accurate materials for the construction of talent teams, personnel exchanges, the use of talent, and promote the rational flow of talent. 


\section{Establish a network management system for cadre personnel file information}

In order to fully share information and improve labor efficiency and work quality, a network management system for file information should be established within the local area network to share information through the network and provide the most up-to-date first-hand information to leaders and departments that need information. Timeliness. The key is to solve the problem of management rights and use rights, and provide the required information by confirming the identity and verifying the password. In addition, confidentiality issues must be resolved. Only by continuously innovating in management concepts, management processes, and management tools can the full play of the proper role of personnel files in colleges and universities. After analysis and estimation, the provisional $\alpha \mathrm{i}$ value is proposed. Formulated as:

$$
\alpha=\mathrm{SX}(1 \mathrm{nSX}) \sum \mathrm{DD}(\mathrm{Mni}-1 \mathrm{DD}) \alpha \mathrm{Wii}=\mathrm{SX}(\alpha 1 \mathrm{~W} 1+\alpha 2 \mathrm{~W} 2+\ldots+\alpha \mathrm{WnnSX})
$$

In analyzing and estimating the experts, they are usually based on the number of scientific and technological files used, the advanced nature of science and technology, the degree of utilization, and the effectiveness of scientific and technological files on their work.

\section{Summary}

The level of political and professional level of the personnel file management team plays an extremely important role in improving the level of personnel management and promoting the pace of personnel reform. In addition to having a good work ethic of a loyal party, ideological style, fair conduct, etc., personnel file management personnel must also possess certain political theory knowledge, modern management knowledge, computer operation skills, personnel management knowledge, and archival business knowledge. At the same time, we must strengthen the training of professional management personnel. We must regularly or irregularly organize relevant training seminars, or go out to visit and study, and constantly improve their political and professional qualities to meet the needs of the modernization management of cadre personnel files.

\section{References}

[1] Lan C L. Thoughts on Strengthening the Management of the Cadres' Personnel Files the in Newly-established Undergraduate Colleges or Universities[J]. Journal of Hechi University, 2006.

[2] Ding J. Thinking on the Files Audit Management of Universities in New Period[J]. Journal of Changzhou Vocational College of Information Technology, 2007.

[3] Cheng L. Information Mnagement of University Cadre Personnel Files[J]. Value Engineering, 2011. 